\title{
Application Methods and Doses of Paclobutrazol Affect Growth, Yield and Fruit Quality of Litchi (Litchi chinensis Sonn.) Cultivars
}

\author{
Ankit Kumar Pandey ${ }^{1 *}$, Prabhakar Singh ${ }^{1}$, Sanjay Kumar Singh ${ }^{2}$ and Kirti Gupta ${ }^{1}$ \\ ${ }^{1}$ Department of Fruit Science, College of Agriculture, Indira Gandhi Agricultural University, \\ Krishak Nagar, 492 012, Raipur, Chhattisgarh, India \\ ${ }^{2}$ ICAR-National Research Centre on Litchi, Muzaffarpur, 842 002, Bihar, India \\ *Corresponding author
}

\begin{tabular}{|l|}
\hline Ke y w or d s \\
Growth, Yield \\
and fruit quality, \\
Litchi, Cultivars. \\
\hline Article Info \\
\hline Accepted: \\
26 June 2017 \\
Available Online: \\
10 August 2017 \\
\hline \hline
\end{tabular}

\section{A B S T R A C T}

The effects of either ring basin (RB) or trunk soil line pore (TSLP) method of application of paclobutrazol (1.00-4.00 g per m canopy diameter) during September, on morphological growth, yield and fruit quality of 2 cultivars of litchi (Litchi chinensis Sonn.) were investigated during 2016-17 in subtropical climate of northern Bihar. The tree height was insignificantly affected but tree girth, canopy height reduced due to higher dose of paclobutrazol (3-4.0 g) applied through trunk soil line pore method. Application of paclobutrazol @ 3.0 or $4.0 \mathrm{~g}$ through TSLP method and $3.0 \mathrm{~g}$ through RB method was found to be better in reducing tree size in terms of canopy volume and diameter. Maximum panicles emerged in the canopy due to $4.0 \mathrm{~g}$ PBZ applied through TSLP method, this dose and methods also led to highest percentage of shoots to flower $(60 \%)$ and $3.0 \mathrm{~g}$ led to early emergence of panicle. TSLP method delayed (2-3 days) the panicle emergence over RB method. $4.0 \mathrm{~g}$ PBZ applied through TSLP method has been yielded maximum no. of fruit per tree (2567.66) while in control it was only 32-140 fruits per tree. $3.0 \mathrm{~g}$ PBZ was also better for enhancing yield, pulp (aril) content over untreated trees. Fruit Size was also affected by methods and doses of application of paclobutrazol but average frit weight was reduced over control due to RB methods, however fruit weight was increased by almost 10 percent over control by application PBZ @ $4.0 \mathrm{~g}$ through TSLP. Upto some extent peel (pericarp) weight got reduced due to application of PBZ through RB method with 2-3.0 g PBZ per $m$ canopy diameter. Although, paclobutrazol had only small effect on morphological parameters but was able to enhanced flowering and yield by many fold after 3.0 or $4.0 \mathrm{~g}$ PBZ applied through TSLP method of application in alternate bearing litchi trees. Therefore, experiment for some more years are required to strengthened scientific argument for reducing alternate bearing tendency in litchi cv. China through application of paclobutrazol with generation of physio-biochemical data of different flushes/shoots.

\section{Introduction}

Litchi (Litchi chinensis Sonn.) is sweet and a very fragrant fruit, which is usually available in the summer month. Tropical climates are conducive to year-round vegetative growth of perennial tropical fruit crops, but flowering and fruit set are usually seasonal. The flushing habit of litchi varieties was intimately connected with irregular bearing. Problem is generally due to failure of flower initiation which puts forth vegetative growth prior to panicle emergence and flowering eliminating the crop completely. In India, litchi produces two growth flushes i.e., first during August followed by the second one 
during November apart from the initial flushing just after fruit harvest. Empirical studies have shown that foliar application of thiourea and potassium nitrate helps in defoliation of pruned tree and in quick emergence of flush and shoot pruning of bearing branches to $20 \mathrm{~cm}$ from the top improved over all plant yield.

The plant produces 3-4 flushes annually i.e. $1^{\text {st }}$ flush during mid-July (30 days after pruning); $2^{\text {nd }}$ flush during late August; $3^{\text {rd }}$ flush during November, $4^{\text {th }}$ and last flush (as mixed flush) during January. Observations on young as well as old 'Calcuttia' litchi trees showed that vegetative growth after September was at the expense of fruiting in the following year (Mustard and Lynch, 1959).

Several research workers advocated the use of various growth retardants as an alternate approach in litchi to restrict vegetative growth before panicle emergence (Chapman et al., 1980). Paclobutrazol, a derivative of triazole are generally more effective in retarding growth when applied to soil or directly to stems as compared to foliar applications (Davis et al., 1988). PBZ is readily taken up through the roots, stems, and leaves, but is transported almost exclusively in the xylem to its site of action, the sub-apical meristem, where it has a persistent effect (Anonymous, 1984). Cultar (paclobutrazol) application 90 days before bud break was found to be more effective than its application 60 days before bud break. Paclobutrazol, thus holds promise in increasing flowering, fruit set, yield and quality of fruits (Faizan et al., 2000). Several methods have been used for applying paclobutrazol to trees. These include foliar sprays, soil surface sprays, trunk drenches, soil injection in narrow bands, and incorporation into potting soil and pressure injection into the vascular system of woody stems.
Significant reduction in vegetative growth has been obtained on peach, sweet cherry and young apple trees with soil applications of paclobutrazol either when injected below the soil surface in the root zone or applied around the tree trunk at the soil line. Unfortunately, our commercial litchi variety 'China' flowers late and does not flower regularly year after year. Flowering is also staggered, leading to considerable variation in fruit maturity. The induction of regular, profuse, early and uniform flowering will undoubtedly ensure higher yields and better returns to the growers. One method to manipulate flowering is to use the plant growth regulator particularly the growth retardants like, paclobutrazol. The post-flushing application of a small amount of paclobutrazol to the soil significantly promotes flowering and fruiting in the following year. Litchi and mango growers can obtain adequate leaf-fruit-ratios with a reliable canopy and plant management system (like practising girdling, manual removal of winter flushes, and application of paclobutrazol during September-October) (Singh et al., 2017).

Accordingly, the current study was proposed with a broad objective of investigating the role of plant growth retardants/ paclobutrazol on floral induction of irregular bearing litchi cultivars with standardised methods and dose of application.

\section{Materials and Methods}

The experiment was conducted during 20162017 at Experimental Farm of ICAR-National Research Centre on Litchi, Mushahari, Muzaffarpur, Bihar. The experimental site is situated at $26^{0} 5^{\prime} 87^{\prime \prime} \mathrm{N}$ latitude, $85^{0} 26^{\prime} 64^{\prime \prime}$ E longitude at an elevation of $210 \mathrm{~m}$ above the mean sea level having a sub-tropical climate. The experimental soil was alluvial with sandy loam texture and are calcareous having $\mathrm{pH} 7.5$ - 8.0. The chosen design was 2 
factor Randomized Block Design (RBD) with spacing of the trees at $8.0 \mathrm{~m} \times 8.0 \mathrm{~m}$ with 12 number of treatments viz. Two methods of application $\left[\left(\mathrm{M}_{1}\right.\right.$ : Ring basin (1.5-2.0 $\mathrm{m}$ away from the trunk) and, $\mathrm{M}_{2}$ : Trunk Soil Line Pore (TSLP) method (near collar region, 2.5 feet away from the tree trunk)] with 5 doses of paclobutrazol [(i.e. $\mathrm{T}_{1}: 1.0 \mathrm{~g}$ a.i. per $\mathrm{m}^{2}$ canopy diameter, $\mathrm{T}_{2}: 2.0 \mathrm{~g}, \mathrm{~T}_{3}: 3.0 \mathrm{~g}, \mathrm{~T}_{4}: 4.0$ $\mathrm{g}, \mathrm{T}_{5}: 0.0 \mathrm{~g}$ (China) and, $\mathrm{T}_{6}: 0.0 \mathrm{~g}$ (Shahi)].

A shallow circular trench (about 10-cm-deep) was dug at a radius of $1 \mathrm{~m}$ from the base of each tree. Paclobutrazol in the water soluble form 'Cultar', was obtained from ICI (Indonesian Operations, Jakarta). The Burondkar and Gunjate (1993) method of soil drenching was followed, in which 10 small holes (10-15 cm depth) was made in the soil around the collar region (2.5 feet away from the tree trunk). A homogeneous solution of PBZ was prepared by dissolving it in 5 litters of tap water and $500 \mathrm{ml}$ of this solution was drenched in each hole. Control trees were drenched with tap water. Drenching was practiced during the first week of September month of first year of experiment. Ten, 12- 15 year old uniform sized litchi cv. China and two trees of Shahi trees were randomly selected for the experiment. Each treatment was replicated thrice with a single tree as a replication unit. All the experimental trees were given uniform cultural practices as recommended by NRCL, Muzaffarpur, Bihar.

Under growth parameters, the observations were recorded on tree height, trunk growth, canopy height, and canopy diameter and canopy volume. The height of the tree was measured vertically from the ground to the tip of the tree and expressed in meter. The tree girth was measured at $30 \mathrm{~cm}$ above from the base and expressed in centimetre. The canopy height was taken from place of first branching of main stem to the apex of the canopy and recorded in meter. The diametric length of the ground space occupied by the tree was measured in two directions and the canopy spread was recorded as "North-South and "East-West directions and final canopy diameter was calculated by addition of both direction divided by 2 . The canopy volume was calculated as per formula of Westwood and Robert (1970), i.e.

Tree volume $\left(\mathrm{m}^{3}\right)=\frac{1}{8} \mathrm{~S}^{2} \pi(\mathrm{H}-0.38)$

Where $\mathrm{S}=$ Mean of spread, $\mathrm{H}=$ Height of tree, $\pi=3.14$

Data were recorded on length of panicle by measuring scale, percentage of shoots flowered; sex ratio was calculated by using the given formula:

Percentage of Shoot flowered $=$ Number of flowered shoots x 100/no. of 100 tagged shoots per tree

Trees were selected at various stages of vegetative flushing ranging from flushes that were just beginning to break dormancy to flushes that were fully mature. The location of panicle emergence was ascertained by counting no. of panicles emerged in particular direction while observing the plants closely during February. Date of first panicle emergence was recorded by observing first panicle emerged in any direction of the canopy of the tree. The date of maximum panicle emergence was noted down when no further emergence of panicles and fruit set was started.

The total number of fruits per panicle and number of fruit per tree was counted in four panicles at five different places in a tree during pea sized fruit stage. The fruit yield was calculated by weighing the total fruits harvested from each tree and weight (in $\mathrm{kg}$ ) was taken by open pan balance. The fruits 
were harvested at proper maturity and only firm uniform sized fruits were selected for further analysis. Fruit size in terms of fruit length and diameter of each harvested fruit was measured at the longest and widest positions, respectively, with the help of a digital Vernier Calliper. Fruit weight (in g) was calculated by recording the weight of 10 fruits on physical balance in each of the three replications. Seed weight, pericarp weight, aril content recorded by taking seeds, peels and pulp of 10 fruits in each of the three replications and average was estimated and unit was $\mathrm{g}$.

The mean was computed for the data on various attributes, whereas a two-factor analysis of variance (ANOVA) using a randomized block design (RBD) was conducted with SAS® 9.2 statistical software for the data on quality parameters. The least significant differences (LSDs) between means at $\mathrm{P}_{0.05}$ and the standard error (SE) of means were computed.

\section{Results and Discussion}

The data pertaining to tree height (m), trunk girth $(\mathrm{cm})$, canopy height $(\mathrm{m})$, canopy diameter $(\mathrm{m})$ and canopy volume $\left(\mathrm{m}^{3}\right)$ recorded during August and February has been presented in table-1 and results indicated that the effect of different doses of paclobutrazol (PBZ) was observed to be significant for trunk girth, canopy height, canopy diameter and canopy volume. Result revealed that the different doses and methods of application of paclobutrazol do not have any significant effect on tree height of treated plant during both observation periods. The trunk girth during August showed significant effect with highest value $(58.00 \mathrm{~cm})$ in $\mathrm{cv}$. China with $2.0 \mathrm{~g}$ PBZ through ring basin method (RB) and $58.40 \mathrm{~cm}$ with $2.0 \mathrm{~g}$ PBZ through trunk line soil pore method (TSLP), which significantly higher than other doses.
However during February, trunk girth was only significantly higher in TSLP methods with 1.0 g PBZ. Gupta and Bist (2005) also found significant decrease in trunk diameter during all the years of study due to paclobutrazol in pear cv. Bagugosa. The canopy height showed significant variation during August whereas canopy diameter varied significantly during February month. The canopy volume has also showed significant improvement during both observation periods with highest value (55.19 $\mathrm{m}^{3}$ ) in RB method and $48.66 \mathrm{~m}^{3}$ in TSLP method with the application $2.0 \mathrm{~g}$ and $1.0 \mathrm{~g}$ PBZ, respectively. Application of PBZ @ 4.0 $\mathrm{g}$ through $\mathrm{RB}$ method reduced canopy volume by less than half.

TSLP method has been found to be less effective in reducing trunk girth than the RB method. Highest reduction in canopy height was recorded with PBZ @2.0 g with RB method between August and February and TSLP method was not able to control much vigour in terms of canopy height, canopy diameter, canopy volume. TSLP methods was also not able to control substantial reduction in canopy volume but against control (almost $>10 \%$ increment during August to February) it has reduced up to $<5$ percent incremental growth. As far as dose in concerned $4.0 \mathrm{~g}$ PBZ has maximum reduced canopy height and diameter. Barar (2010) in guava cv. Sardar, also observed plant spread in E-W and $\mathrm{N}-\mathrm{S}$ direction to be maximum in control plants and maximum restriction of canopy spread with PBZ @ 500 ppm in E-W direction.

The canopy volume reduced maximum in the treatment $3.0 \mathrm{~g}$ PBZ irrespective of method of application. According to Gupta and Bist (2005), the growth attributes, viz. annual tree height increment, trunk diameter, canopy spread and leaf area was effectively controlled by TSLP applied paclobutrazol @ 
of $10 \mathrm{ml}$ per tree in 'Bagugosa' pear. The result presented in table 2 reflected that $1.0 \mathrm{~g}$ PBZ with ring basin has been found effective for highest no. of panicle emergence followed by control plants. PBZ @ 4.0 g applied through TSLP method also produced substantial no. of panicles in all the direction.

Application of PBZ @ $1.0 \mathrm{~g}$ has enhances no. of panicle emergence by 5 times in comparison to control (China) but tree treated with PBZ @ 4.0 g with TSLP method could increased 100 times panicle emergence than the control (4 in No.s). Date of panicle emergence was advanced by a week after trees received $3.0 \mathrm{~g}$ PBZ applied through TSLP method during September-October. There was not much variation in date of first panicle emergence by RB method of application of PBZ but later method (RB) has been able to complete maximum panicle emergence within shorter period than the TSLP method. TSLP methods has delayed maximum panicle emergence by 2-3 days (table 2).

Evergreen tree litchi cv. China exhibits alternate bearing tendency and proper crop regulation is essential to encourage sufficient number of panicles per $\mathrm{m}^{2}$ canopy area and number of panicle per tree, so that the higher productivity could be achieved. Litchi flushing and subsequent flowering of the tagged shoots (branches) resulted only from the development of the apical buds. Litchi flowering was commenced during February or March 2017. To ascertain differences in flowering time in relation to treatment, inflorescence development on the tagged branches was monitored weekly. It was noticed that application of PBZ @ $4.0 \mathrm{~g}$ with TSLP has been effective for highest no. of shoot $(60 \%)$ to be flowered against control $(5.0 \%)$. Ring basin method could not had much influence on percent shoot flowered over tagged shoots, sometimes reduced (5-30
$\%)$ or no better than control plants $(30.0 \%)$ Higher dose (3-4 g PBZ) has been found to be better for inducing floral shoots in tagged branches. In general, triazoles, owing to its anti-gibberellin activity, could induce or intensify flowering by blocking the conversion of kaurene to kaurenoic acid (Voon, et al., 1991). There was insignificant difference was observed (table 3) due to method of application or dose of PBZ on sex ratio parameters, however sex ratio improved by application of PBZ through TSLP method. Nunez et al., (1993) reported that paclobutrazol and uniconazole possibly increased flowering rate and related characters by preventing shoot elongation leads to more light interception and movement of assimilate partitioning and caused rapid development of reproductive buds by interfering with gibberellin metabolism. Panicle length was found to be highest $(17.81 \mathrm{~cm})$ in tree applied with PBZ @ $4.0 \mathrm{~g}$ by TSLP method followed by tree got PBZ @ 3.0 g but overall panicle length was found to be higher over control $(15.90 \mathrm{~cm})$ even in ring basin method of application irrespective of doses. Here paclobutrazol as induced inhibition in tree vigour and promotion of flowering in mango is not only associated with the gibberellin biosynthesis inhibiting character of paclobutrazol but also with its influence on other hormones such as ABA, cytokinins and IAA and as also on phenol (Murti et al., 2001). As per table 3, TSLP helps the litchi trees to record higher yield (i.e upto $70.0 \mathrm{~kg}$ fruit per tree due to PBZ @ 4.0 g per m canopy diameter followed by $3.0 \mathrm{~g}$ PBZ), lesser dose of PBZ (1.0 g per $\mathrm{m}$ canopy diameter) applied through ring basin method was found to be significant for improvement in yield which had higher no. of fruits per panicle (22.00) or per tree (330.00). Exceptionally, highest no. of fruit per tree (2567 fruit per tree) was recorded with TSLP application of PBZ @ $4.0 \mathrm{~g}$ which had also highest no. of fruit per panicle (22.00). 
Table.1 Effect of methods of application and doses of paclobutrazol on morphological parameters (Tree height, girth, canopy diameter, canopy height and canopy volume) in litchi cvs. Shahi and China

\begin{tabular}{|c|c|c|c|c|c|c|c|c|c|c|c|}
\hline \multirow[t]{2}{*}{ Treatments } & \multirow[t]{2}{*}{ Dose of PBZ } & \multicolumn{2}{|c|}{ Tree Height $(m)$} & \multicolumn{2}{|c|}{ Trunk Girth $(\mathrm{cm})$} & \multicolumn{2}{|c|}{ Canopy Height $(\mathrm{m})$} & \multicolumn{2}{|c|}{ Canopy Diameter $(m)$} & \multicolumn{2}{|c|}{ Canopy Volume $\left(\mathrm{m}^{3}\right)$} \\
\hline & & August & February & August & February & August & February & August & February & August & February \\
\hline \multirow{6}{*}{$\begin{array}{l}\text { Ring Basin } \\
\text { Methods }\end{array}$} & 1.0 & 3.66 & 3.73 & 55.33 & 52.60 & 3.10 & 3.26 & 4.90 & 4.95 & 41.06 & 41.84 \\
\hline & 2.0 & 4.06 & 4.10 & 58.00 & 59.50 & 4.13 & 3.56 & 5.03 & 5.26 & 55.19 & 51.54 \\
\hline & 3.0 & 3.83 & 3.58 & 53.33 & 53.33 & 2.80 & 2.58 & 4.86 & 4.70 & 34.74 & 29.93 \\
\hline & 4.0 & 3.60 & 3.35 & 51.00 & 51.10 & 2.80 & 2.71 & 3.70 & 3.53 & 20.13 & 17.84 \\
\hline & Control (China) & 3.83 & 4.00 & 55.33 & 55.00 & 3.16 & 3.48 & 5.33 & 5.65 & 47.13 & 56.02 \\
\hline & Control (Shahi) & 4.33 & 3.83 & 64.33 & 69.56 & 3.36 & 3.43 & 6.40 & 6.71 & 75.22 & 80.49 \\
\hline \multirow[t]{6}{*}{ TSLP } & 1.0 & 3.83 & 3.75 & 58.00 & 60.40 & 3.53 & 3.48 & 5.13 & 6.40 & 48.66 & 77.53 \\
\hline & 2.0 & 3.56 & 3.66 & 58.40 & 60.23 & 3.00 & 3.00 & 5.40 & 5.40 & 45.82 & 47.31 \\
\hline & 3.0 & 3.86 & 3.71 & 50.83 & 51.46 & 2.73 & 3.06 & 4.48 & 4.33 & 28.61 & 29.81 \\
\hline & 4.0 & 3.50 & 3.43 & 50.06 & 56.83 & 2.51 & 2.91 & 4.76 & 5.30 & 29.86 & 44.88 \\
\hline & Control (China) & 3.66 & 3.41 & 54.76 & 57.33 & 2.66 & 3.00 & 5.33 & 5.50 & 39.97 & 43.39 \\
\hline & Control (Shahi) & 3.53 & 4.07 & 52.00 & 51.93 & 3.16 & 3.54 & 5.71 & 5.80 & 52.14 & 57.03 \\
\hline \multirow[t]{3}{*}{$\mathrm{CD}_{0.05}$} & A & NS & NS & 2.10 & $\mathrm{NS}$ & 0.25 & NS & NS & 0.04 & 4.29 & 3.33 \\
\hline & B & NS & NS & 3.63 & 2.55 & 0.43 & 0.31 & 0.18 & 0.07 & 7.44 & 5.77 \\
\hline & $\mathrm{A} \times \mathrm{B}$ & NS & NS & 5.14 & 3.61 & 0.61 & 0.43 & 0.26 & 0.10 & 10.52 & 8.17 \\
\hline \multirow[t]{3}{*}{ SEM \pm} & A & 0.10 & 0.08 & 0.71 & 0.50 & 0.08 & 0.06 & 0.03 & 0.01 & 1.45 & 1.13 \\
\hline & $\mathrm{B}$ & 0.17 & 0.13 & 1.23 & 0.86 & 0.14 & 0.10 & 0.06 & 0.02 & 2.52 & 1.95 \\
\hline & $\mathrm{A} \times \mathrm{B}$ & 0.24 & 0.19 & 1.74 & 1.22 & 0.20 & 0.15 & 0.09 & 0.03 & 3.56 & 2.76 \\
\hline
\end{tabular}

Table.2 Effect of methods of application and doses of paclobutrazol on emergence of flushes and time of Panicle emergence in litchi cvs. Shahi and China

\begin{tabular}{|c|c|c|c|c|}
\hline Treatments & Dose of PBZ & Location and Distribution of Panicle & Date of First panicle emergence & Date of Maximum Panicle emergence \\
\hline \multirow[t]{6}{*}{ Ring Basin Methods } & 1.0 & $\mathrm{~N}-28, \mathrm{E}-23, \mathrm{~W}-28, \mathrm{~S}-25$ & $18^{\text {th }}$ February & $25^{\text {th }}$ February \\
\hline & 2.0 . & N-0, E-0, W-0, S-1 & $16^{\text {th }}$ February & $25^{\text {th }}$ February \\
\hline & 3.0 & $\mathrm{~N}-0, \mathrm{E}-2, \mathrm{~W}-0, \mathrm{~S}-1$ & $16^{\text {th }}$ February & $25^{\text {th }}$ February \\
\hline & 4.0 & N-0, E-1, W-1, S-1 & $17^{\text {th }}$ February & $25^{\text {th }}$ February \\
\hline & Control (China) & N-3, E-15, W-0, S-0 & $16^{\text {th }}$ February & $26^{\text {th }}$ February \\
\hline & Control (Shahi) & $\mathrm{N}-27, \mathrm{E}-8, \mathrm{~W}-6, \mathrm{~S}-26$ & $15^{\text {th }}$ February & $23^{\text {rd }}$ February \\
\hline \multirow[t]{6}{*}{ TSLP } & 1.0 & $\mathrm{~N}-0, \mathrm{E}-1, \mathrm{~W}-0, \mathrm{~S}-1$ & $16^{\text {th }}$ February & $25^{\text {th }}$ February \\
\hline & 2.0. & $\mathrm{~N}-0, \mathrm{E}-0, \mathrm{~W}-27, \mathrm{~S}-0$ & $17^{\text {th }}$ February & $27^{\text {th }}$ February \\
\hline & 3.0 & $\mathrm{~N}-31, \mathrm{E}-7, \mathrm{~W}-41, \mathrm{~S}-7$ & $10^{\text {th }}$ February & $28^{\text {th }}$ February \\
\hline & 4.0 & N-50, E-62, W-111, S-105 & $17^{\text {th }}$ February & $27^{\text {th }}$ February \\
\hline & Control (China) & $\mathrm{N}-2, \mathrm{E}-1, \mathrm{~W}-0, \mathrm{~S}-1$ & $16^{\text {th }}$ February & $26^{\text {th }}$ February \\
\hline & Control (Shahi) & N-3, E-4, W-0, S-3 & $15^{\text {th }}$ February & $22^{\text {nd }}$ February \\
\hline
\end{tabular}


Table.3 Effect of methods of application and doses of paclobutrazol on floral and yield attributes in litchi cvs. Shahi and China

\begin{tabular}{|c|c|c|c|c|c|c|c|}
\hline Treatments & Dose of PBZ & Percent shoot flowered* & Sex ratio & Panicle length $(\mathrm{cm})$ & No. of Fruits per panicle & No. of Fruit per tree & Fruit Yield per tree \\
\hline Ring & 1.0 & $30.00(33.19)$ & 2.77 & 15.86 & 22.00 & 330.00 & 8.29 \\
\hline \multirow{5}{*}{ Methods } & 2.0 . & $15.00(22.77)$ & 2.76 & 16.06 & 5.00 & 20.00 & 0.48 \\
\hline & 3.0 & $5.00(12.87)$ & 0.00 & 0.00 & 5.00 & 23.00 & 0.58 \\
\hline & 4.0 & $5.00(12.87)$ & 0.00 & 0.00 & 6.00 & 26.00 & 0.61 \\
\hline & Control (China) & $28.00(31.93)$ & 2.75 & 15.90 & 21.00 & 140.00 & 5.13 \\
\hline & Control (Shahi) & $30.00(33.19)$ & 2.99 & 13.53 & 18.00 & 120.00 & 2.46 \\
\hline \multirow[t]{6}{*}{ TSLP } & 1.0 & $10.00(18.41)$ & 0.00 & 0.00 & 7.00 & 28.00 & 0.70 \\
\hline & 2.0 . & $20.00(26.55)$ & 2.83 & 14.63 & 6.00 & 30.00 & 0.76 \\
\hline & 3.0 & $55.00(47.85)$ & 2.86 & 16.61 & 8.00 & 736.00 & 19.35 \\
\hline & & $60.00(50.75)$ & 2.89 & 17.81 & 22.00 & $2,567.66$ & 70.00 \\
\hline & Control (China) & $5.00(12.87)$ & 0.00 & 0.00 & 12.67 & 32.00 & 0.81 \\
\hline & Control (Shahi) & $11.00(19.35)$ & 0.00 & 0.00 & 27.00 & 35.00 & 0.74 \\
\hline \multirow[t]{3}{*}{$\mathrm{CD}_{0.05}$} & A & $0.44(0.40)$ & 0.008 & 0.21 & 0.43 & 0.57 & 0.20 \\
\hline & $\mathrm{B}$ & $0.76(0.70)$ & 0.014 & 0.37 & 0.74 & 0.98 & 0.35 \\
\hline & $\mathrm{A} \times \mathrm{B}$ & $1.08(0.99)$ & 0.02 & 0.52 & 1.05 & 1.39 & 0.50 \\
\hline \multirow[t]{3}{*}{ SEM \pm} & A & $0.15(0.14)$ & 0.003 & 0.072 & 0.14 & 0.19 & 0.07 \\
\hline & $\mathrm{B}$ & $0.26(0.24)$ & 0.005 & 0.125 & 0.25 & 0.33 & 0.12 \\
\hline & $A \times B$ & $0.37(0.33)$ & 0.007 & 0.17 & 0.35 & 0.47 & 0.17 \\
\hline
\end{tabular}

$*$ Values in the parenthesis is transformed value through Angular transformation for normalizing the frequency distribution

Table.4 Physico-chemical characters of litchi fruit affected by methods of application and doses of Paclobutrazol in litchi cvs. Shahi and China

\begin{tabular}{|c|c|c|c|c|c|c|c|}
\hline Treatments & Dose of PBZ & Fruit length $(\mathrm{cm})$ & Fruit Diameter $(\mathrm{cm})$ & Fruit weight $(\mathrm{g})$ & Seed weight $(\mathrm{g})$ & Pericarp weight $(\mathrm{g})$ & Aril content $(\mathrm{g})$ \\
\hline Ring Basin & 1.0 & 3.25 & 3.45 & 25.20 & 1.32 & 4.02 & 18.40 \\
\hline \multirow[t]{5}{*}{ Methods } & 2.0 . & 3.55 & 3.47 & 24.63 & 1.35 & 3.82 & 18.80 \\
\hline & 3.0 & 3.15 & 3.42 & 25.60 & 1.36 & 3.80 & 19.10 \\
\hline & & 3.19 & 3.46 & 23.60 & 1.32 & 4.04 & 18.30 \\
\hline & Control (China) & 3.54 & 3.51 & 26.67 & 1.33 & 4.05 & 18.80 \\
\hline & Control (Shahi) & 3.26 & 3.28 & 20.43 & 3.82 & 3.42 & 15.18 \\
\hline \multirow[t]{5}{*}{ TSLP } & 1.0 & 3.15 & 3.52 & 25.30 & 1.36 & 4.02 & 18.80 \\
\hline & 2.0 . & 3.43 & 3.54 & 25.53 & 1.34 & 4.04 & 18.90 \\
\hline & 3.0 & 3.45 & 3.56 & 26.30 & 1.32 & 4.03 & 19.10 \\
\hline & Control (China) & 3.36 & 3.52 & 25.37 & 1.32 & 3.80 & 19.00 \\
\hline & Control (Shahi) & 3.27 & 3.27 & 21.30 & 3.82 & 3.42 & 15.12 \\
\hline \multirow[t]{3}{*}{$\mathrm{CD}_{0.05}$} & A & 0.006 & 0.003 & 0.117 & NS & 0.033 & 0.039 \\
\hline & B & 0.010 & 0.004 & 0.203 & NS & 0.057 & 0.068 \\
\hline & $\mathrm{A} \times \mathrm{B}$ & 0.014 & 0.006 & 0.287 & NS & 0.081 & 0.096 \\
\hline \multirow[t]{3}{*}{ SEM \pm} & A & 0.002 & 0.001 & 0.040 & 0.001 & 0.011 & 0.013 \\
\hline & B & 0.003 & 0.001 & 0.069 & 0.001 & 0.019 & 0.023 \\
\hline & $\mathrm{A} \times \mathrm{B}$ & 0.005 & 0.002 & 0.097 & 0.001 & 0.027 & 0.032 \\
\hline
\end{tabular}


Negi and Sharma (2011) also recorded fruit yield $(\mathrm{kg} /$ tree $)$ significantly high on trees treated with paclobutrazol in peach cv. July Elberta. Davis et al., (1988) also applied PBZ to the soil and found that a continuous supply of paclobutrazol might have taken up by the roots which is translocated acropetally via the xylem, thus maintaining the concentration of paclobutrazol above the threshold required for the inhibition of gibberellins biosynthesis and subsequently yield was enhanced. Control trees of 'China' and 'Shahi' recorded very meagre yield (0.81, $0.74 \mathrm{~kg}$ per tree) (table 3$)$. Fruit yield, size, weight, volume, colour, firmness and organoleptic rating in terms of taste, texture, flavour and TSS was significantly improved by combined application of paclobutrazol and summer prunings in comparison to control and other treatments (Ashraf et al., 2015). Our results were in congruence of finding of Anusuya and Selvarajan (2014) who found that the paclobutrazol at $0.75 \mathrm{~g}$ a.i. applied during September was the best with the highest yield (248.50 per tree) which was due to increased number of hermaphrodite flowers per panicle, number of flowers per panicle and total phenols content.

The fruit length, diameter and fruit weight, pericarp weight and aril content was found to be significantly affected by methods of application, doses and their interaction effects (table 4). The fruit length was highest (3.55, $3.56 \mathrm{~cm}$ ) in the trees receiving 2. $0 \mathrm{~g} \mathrm{PBZ}$ with RB method and $4.0 \mathrm{~g}$ PBZ with TSLP method, respectively, control trees had lesser fruit length $(3.36 \mathrm{~cm})$. The fruit size in term of diameter has also been affected by application of PBZ applied through TSLP method and increased significantly, however fruit diameter and fruit weight decreased meagrely by PBZ application through RB method. The increase in fruit length and breadth may be attributed to the fact that paclobutrazol spray reduced the vegetative growth (sinks) which, in turn, increased the partitioning of nutrients and dry matter towards fruits and thereby enhanced fruit size and weight (Wolstenholme et al., 1990).The fruit weight was found to be higher $(27.30 \mathrm{~g})$ due to application of PBZ @ $4.0 \mathrm{~g}$ with TSLP method which was almost 10 percent higher than the weight of fruit from control trees (25.37 g). Ring basin method did not improve fruit weight which might be due to higher fruit per panicle in the treated trees. Seed weight was not significantly affected by method or dose of application of PBZ in litchi trees. RB method of application has been found to be better for reducing pericarp weight with dose of 2-3.0 g PBZ. Aril content has also improved over control (18.80 g) due to application of PBZ @ $3.0 \mathrm{~g}$ (19.10 g) with any methods of application but TSLP methods was better than the RB method. Menzel and Simpson (1990) also found that paclobutrazol had only a small effect on panicle development, fruit set and fruit quality at most site in litchi trees.

While paclobutrazol was effective in controlling vegetative growth, conflicting evidence on paclobutrazol induced changes in growth and fruit quality attributes in litchi suggests that further investigation is required.

\section{References}

Anonymous, 1984. Paclobutrazol: Plant Growth Regulator for Fruit. I. C. I. Technical Data Sheet. 42pp

Anusuya, P., and M Selvarajan. 2014. Effect of dose and time of paclobutrazol application on physiology of flowering and yield in mango (Mangifera indica L.) cv. Alphonso. Trends in Biosciences 7(12): 1213-1216

Ashraf, Naira, M.Y., Bhat, M.K. Sharma, G.H. Rather, Moieza Ashraf, M.A. Dar and Rifat Ara. 2015. Effect of paclobutrazol and summer pruning on 
yield and fruit quality of apple cv. 'red delicious'. Applied Biol. Res. 17(2): 166-173

Barar, J. S., 2010. Influence of Paclobutrazol and Ethephon on Vegetative Growth of Guava (Psidium guajava L.) Plants at Different Spacing, Nat. Sci. Biol. 2 (3):110-113

Burondkar, M.M., and R.T. Gunjate. 1993. Control of vegetative growth and induction of regular and early cropping in 'Alphonso' mango with Paclobutrazol. Acta Hort. 341:206-215

Chapman, K.R., Paxton, B. and Cull, B.W. 1980. Litchi cultivar evaluation (Project 1), Bienn. Rep. Maroochy Horticulture Research Station, 2: 32-33

Davis T. D., Steffens, G. L. and Sankhla N. 1988. Triazole plant growth regulators. In: Janick J. (ed.): Horticultural Reviews. 10: 63-105. John Wiley \& Sons Inc., Toronto

Faizan, A., Mohammad A and Ganesh K. 2000. Effect of paclobutrazol on growth, yield and quality of litchi (Litchi chinensis Sonn.). Indian J. Hort., 57 (4): 291-294

Gupta, N.K., and Bist, L.D. 2005. Effect of different planting systems and paclobutrazol on vegetative growth of Bagugosa pear. Indian J. Hort. 62(1):20-23

Menzel, C.M. and Simpson, D.R. 1990. Effect of paclobutrazol on growth and flowering of lychee (Litchi chinensis). Australian J. Expt. Ag. 30(1):131 - 137
Murtii, G.S.R., Upreti K.K., Kurian, R.M. and Reddy, Y.T.N. 2001. Paclobutrazol modifies Tree Vigour and Flowering in Mango cv. Alphonso. Indian J. Plant Physiol., 6(4): 355-360

Mustard, M.J., and Lynch, S. J. 1959. Notes on litchi panicle development. Proc. Fla. St. Hort., Soc., 72: 324-27

Negi, N. D., and Sharma N. 2009. Effect of paclobutrazol application and planting systems on growth and production of peach (Prunus persica). Indian J. Ag. Sc. 79: 1010-12

Nunez, E. R., Davenport, T. L. and Caldeira, M. L. 1993. Bud initiation and morphogenesis in 'Tommy Atkins' mango as affected by temperature and triazole growth retardants. Acta Hort., 341:192-198

Singh, Sanjay Kumar, Nath, Vishal; Marboh, E. S., and Sharma, Swati. 2017. SourceSink Relationship in Litchi verses Mango: A Concept. International $J$. Current Microbiology and Applied Sci., 6 (3): 500-509

Voon, C. H., Pitakpaivan, C. and Tan, S.J. 1991. Mango cropping manipulation with Cultar. Acta Hort., 291: 219-228.

Wolstenholme, N., Whiley, W. and Saranah, J.B. 1990. Manipulating vegetative and reproductive growth in avocado (Persea americana Mill.) with paclobutrazol foliar sprays. Scientia Hort., 41: 315327.

\section{How to cite this article:}

Ankit Kumar Pandey, Prabhakar Singh, Sanjay Kumar Singh and Kirti Gupta. 2017. Application Methods and Doses of Paclobutrazol Affect Growth, Yield and Fruit Quality of Litchi (Litchi chinensis Sonn.) Cultivars. Int.J.Curr.Microbiol.App.Sci. 6(8): 3280-3288. doi: https://doi.org/10.20546/ijcmas.2017.608.391 